\title{
Can Rights Be Frozen?
}

\begin{abstract}
This chapter focuses on the intension of Union citizenship by asking if rights can be frozen. In particular, we look at the extra-negotiational legal resources available for freezing rights of the people involved. Can rights be frozen? Which rights? Whose rights? Under what conditions? For how long? Sources of international law and EU law, including guidelines from lesser-known sources and doctrinal instruments, are taken into account. The conclusion is that some rights of some of the people involved will be frozen, but that the legal grounds for doing so suggests that Union citizenship is not what the European Court of Justice and most scholars claim it is.
\end{abstract}

Keywords European citizenship - Functionalist theory of citizenship Brexit - Freedom of movement - Right of residence - EU law - Migration law $\cdot$ International law

This chapter explores the content side of citizenship, its intension. Let us turn to entitlements and ask if rights can be frozen. In particular, we look at the extra-negotiational legal resources available for freezing rights of the people involved. Can rights be frozen? Which rights? Whose rights? Under what conditions? For how long? On what grounds?

We examine sources of international law and EU law, including guidelines from lesser-known sources and doctrinal instruments. To do so, analogous reasoning will be applied to the unprecedented situation. ${ }^{1}$

(C) The Author(s) 2017

P. Mindus, European Citizenship after Brexit, Palgrave Studies in European Union Politics, DOI 10.1007/978-3-319-51774-2_5 
Analogy is never a purely logical argument and ought to be taken cum granu salis. ${ }^{2}$ More modestly, analogies explored here will merely help to enucleate guidelines.

The conclusion is that some rights of some of the people involved can be frozen, but that the legal grounds for doing so suggests that Union citizenship is not what the European Court of Justice and most scholars claim it is.

\subsection{Lessons From International LaW}

International law does not regulate explicitly a matter like the loss of European citizenship for UK citizens, nor the loss of territorial EU citizenship rights for second country nationals in the UK. Some have argued that British expats in the Union would have 'acquired rights' under the 1969 Vienna Convention on the Law of Treaties (VCLT). Reference is to vested rights under Article 70(1)(b) VCLT and to the formula '(b) does not affect any right, obligation or legal situation of the parties created through the execution of the treaty prior to its termination.' This source of international law is an unlikely candidate for protecting acquired rights. ${ }^{3}$ It is unclear, to say the least, if such a notion could be used in the first place; if it would cover the situation; if it would cover all rights; or else, which rights? whose rights? and with what exact practical impact? Retaining 'executed' rights - that is, those rights that are not automatically revoked if a treaty or law no longer applies, and that can be retained even in the event of a change in the ultimate power over a country - refers to 'private' rights, whereas EU citizens' rights include highly 'public' rights, for example, voting and standing in elections at local and European level. Not much solace is to be found in this reference to international law.

The ban on arbitrary deprivation of citizenship recurrent in many international instruments - others venture - might have some bearing: As things currently stand, 'questions are bound to arise, should the withdrawing state be willing to retroactively terminate the rights enjoyed by EU citizens connected with other member states in its own territory' (Kochenov 2016). Yet, it would be limited to cases of retroactive restrictions and would therefore be silent on the situation of post-exit restrictions.

Can international law at least provide us with guidelines as to what happens to Union citizenship in the case at hand? If we look at how nationality matters have been regulated in state succession scenarios, 
some interpretative aids may be distilled. The analogical reasoning is warranted by the fact that the problems, which secessions pose to citizenship at the national level, are very similar to the problems posed by withdrawals from the EU in relation to Union citizenship (Closa 2014), even though there are limits to the analogy: The EU is not a state; it is difficult to argue for the existence of a change in sovereignty; no new nationality law needs to be written. Previous experiences cannot easily be made to fit Brexit, especially considering the emphasis of the European Court of Justice on Union citizenship being the fundamental status of nationals of member states.

There are three lessons to learn from the state succession literature as far as guiding principles are concerned: The leaving country and the remaining bloc have a duty to negotiate solutions, the leaving country has a duty to inform and possibly to suggest options for individuals concerned.

\subsubsection{Duty to Negotiate Solutions}

From the legal doctrine on succession, we learn that there is a general obligation to seek negotiated solutions. Consider, for example, Article 19 of the European Convention on Nationality from 1997 (ECN) that substantially repeats the Art. 10(1) of the 1961 Convention on Statelessness: 'In cases of state succession, state parties concerned shall endeavour to regulate matters relating to nationality by agreement amongst themselves and, where applicable, in their relationship with other States concerned.' The 'duty' of reaching negotiated solutions is a consistent feature of international instruments dealing with state succession. In September 2012 the Union made a formal pledge that all member states will consider ratification. ${ }^{4}$ The UK, however, has not signed: 'The 'duty' to negotiate is also reinforced at EU level on the side of the predecessor EU member state which must observe the principle of proportionality [and other general principles of EU law] when drafting the new nationality legislation in the event of the independence of part of its territory' (Gonzalez Marrero 2016, 108).

The obligation to negotiate was also mentioned in the decision of the Supreme Court of Canada Reference re Secession of Quebec. In the advisory Opinion by the Canadian Supreme Court issued at request of the government on the issue of secession of Quebec, the court found that:

the federalist principle, in conjunction with the democratic principle, dictates that the clear repudiation of the existing constitutional order and the clear 
expression of the desire to pursue secession by the population of a province would give rise to a reciprocal obligation on all parties to the Confederation to negotiate constitutional changes to respond to that desire ( ...). The corollary $(\ldots)$ is an obligation on all parties to come to the negotiation table. ${ }^{5}$

There may thus be a constraint on the possibilities of limiting 'acquired rights' of UK nationals in EU27. It has been suggested that 'UK citizens in the EU would have a legal position inferior to Russians and Moroccans (whose countries have non-discrimination agreements with the EU)' (Kochenov 2016) but the duty to negotiate solutions would not be compatible with such treatment.

\subsubsection{Duty to Inform}

An interesting source relating to this guideline is the UN International Law Commission's Draft Articles on Nationality of Natural Persons in Relation to the Succession of States from 1999. ${ }^{6}$ The Draft Articles require all appropriate steps to be taken to 'ensure persons concerned will be informed, within a reasonable time period, of the effect of its legislation on their nationality' (Art. 6). It is not unreasonable to assume that it would be valid also in the event of exit from international organisation such as the EU. The rationale of the duty to inform is that persons concerned 'should not be reduced to a purely passive role as regards the impact of the succession of States on their individual status or confronted with adverse effects of the exercise of a right of option of which they could objectively have no knowledge when exercising such a right. ${ }^{7}$ The Draft Articles are not binding and, after deferral, the topic has disappeared from the UN general assembly's agenda. This source may nonetheless be said to provide relevant guidelines.

In event of Brexit, the UK would need to inform persons concerned, that is, both second country nationals in the UK and British nationals in the Union of 'the effect of its legislation on their nationality.' This duty to inform does not seem to have been considered. It can be read as a limit to using citizens of either side as 'bargaining chips in negotiations' contrarily to suggestions made by several British politicians, including Theresa May, at the end of June and repeated on several occasions. This position was not modified in the speech on the Brexit plan delivered at Lancaster House 17 January 2017. Indeed, merely leaving it up for behind closed-door negotiations to settle the issue would potentially deprived 'persons concerned' of knowledge of 'the effect of [the] legislation on their nationality.' Exchange of information and consultations 
between States are fundamental to identify the negative consequences that may arise for the status of the persons concerned and for the issues linked to the status. There is an 'obligation' - of positive morality, to use Austin's phrase - to provide clearness on nationality matters (promotion of legal certainty) so as to reduce the number of potential hard cases and secure, as far as possible, rights acquired under the previous legal setting.

\subsubsection{Right to Option}

States involved in succession shall give consideration to the will of persons concerned especially nationals of the predecessor state. Article 18 of the European Convention on Nationality formulates a list of criteria to be taken into account in case of state succession, without indicating a principle for weighting these. One criterion to be reckoned with is 'the will of the person.' This source binds 13 member states, but not the UK. This guideline, however, also appears in other sources: Art. 24 and 25 of the Involuntary Loss of European Citizenship Draft Articles also provide for the predecessor state to deprive persons of 'old' citizenship in case they acquire the successor state's nationality - 'unless otherwise indicated by the exercise of a right of option.' The possible consequences that may derive from the non-binding guideline centred on providing a right to option is less clear than the previous two guidelines. What would a right to option be in the Brexit case? In case of state succession within the EU, for example, Scotland, Flanders or Catalonia, the choice would be between Scottish and British, Flemish and Belgian or Spanish and Catalan membership. But in the case of Brexit it is unclear what 'choice' would imply. If honouring the international legal guideline were a priority - which it is not - a choice ought to be offered in view of easing naturalisation for UK nationals in certain member states. ${ }^{8}$ Being serious about this guideline might also mean that UK nationals in the remaining states should be offered the possibility of acquiring 'predecessor status' or the status in virtue of which they established themselves there in the first place, which might imply giving UK citizens around the EU some form of non-temporary right to stay. However, other legal positions linked to their prior Union citizenship status would not be covered, such as the anchorage of pensions to the EU system.

Occasionally, there is mention of protection of acquired rights for third country nationals; notwithstanding that, generally, nationals of countries not involved in the State succession yet residing in the territory of the 
successor State receive little or no attention. This category of people seems to be forgotten in most international instruments dealing with nationality and State succession: Neither the European Convention on Nationality nor the Convention on Avoidance of Statelessness in Relation to State Succession addresses the situation of nationals of third countries residing on the territory of the successor state.

Guayasén Gonzalez Marrero, who has recently completed a systematic study of international legal instruments pertaining to nationality in state succession scenarios, claims that, notwithstanding this general silence, the protection of the acquired rights of third country nationals may also be added: 'Perhaps providing a right to opt for the nationality of the newly independent State could be seen as going too far, but at least it seems desirable to preserve their status as permanent residents' (Gonzalez Marrero 2016, p. 110). One source to read in this direction is, for instance, the Venice Declaration of the Council of Europe that provides that where third country nationals are permanently settled on the territory, it may be possible for them to acquire the nationality of the successor state. ${ }^{9}$ In this light we ought to read Article 16 of the Venice Declaration: 'The exercise of the right to choose the nationality of the predecessor state, or of one of the successor States, shall have no prejudicial consequences for those making that choice, in particular with regard to their right to residence in the successor state.'

Weighting in third country nationals into the equation concerning the right to option could mean, in the case of Brexit, that third country nationals who are family members of second country nationals in the $\mathrm{UK}$ are to be offered some leave to remain, even in cases not immediately covered by the domestic legislation.

\subsection{Saving Citizens' Rights?}

It is clear from the softness of the sources foreshadowed above that opportunities for freezing rights will need to be found elsewhere. The remedy venues open to post-Europeans are different from those of second country nationals in the UK since member states are continuously bound by European law. As third country nationals in the Union, British citizens resident in member states may fall within the ambit of EU law with the effect that they would be able to invoke EU general principles of law and the Charter of Fundamental Rights of the European Union in respect of their rights. They would, however, do so as third country nationals, and 
no longer as European citizens. ${ }^{10}$ For many: 'Brexit presents the EU with an opportunity to clearly demonstrate the high value of European citizenship if UK nationals living in other member states can be assured that they will not lose their EU citizenship rights but rather that those rights will be 'frozen' on the day the UK formally 'leaves' the Union' (Carrera et al. 2016). How can this be done?

Residence rights can be maintained as derived from the existence of family ties with European citizens. British citizens who are family members of Union citizens are better off than those without such connections: (s)he would fall within the scope of the Citizens Directive, which provides for residence rights. Some EU doctrinal constructs reinforce this claim. The famous $Z h u$ and Chen doctrine could impact on a member state exit scenario in which the nationality of a child be such that the child is a Union citizen and has nationality separate from that of the parents who hold the nationality of the exiting state.

The case giving name to the doctrine concerned Catherine $\mathrm{Zhu},{ }^{11}$ a child born with Irish nationality ex iure soli, following the deliberate choice of her Chinese parents to have the child delivered in Belfast to guarantee Union citizenship be bestowed upon her. The European Court of Justice concluded that the UK could not deny the right of residence of Catherine merely because her Union citizenship had been acquired to assure residence rights for the third country national parent. The mother was recognised a right to residence in the UK on the grounds that she was primary carer to a minor Union citizen residing there.

The doctrine may have bearing on situations in which a child is born in another European member state that allows for ius soli at birth. In such a case, the parents of the child, as primary carer, could be granted residence rights in the Union so as not to deprive the child's rights to residence of any useful effect. Consider, for example, the case of the child who acquired Union citizenship though nationality of a member state ex iure soli, by birth on the territory, and the parents have UK nationality but the child does not; either because the parents are unable to pass on their nationality ex iure sanguinis or because the child is born on the territory of another state who does not recognise the possibility for the child to hold multiple nationalities. Such cases may derive from a combination of British and EU member state provisions. Consider, for example, the UK nationality law, according to which a person born abroad to a citizen - who acquired citizenship by descent, and is not in public service - does not acquire citizenship automatically, and is prevented from doing so through 
registration in the event the parent(s) have not resided at any time in the UK for three years. If these provisions are taken in a combination with the nationality provisions in Austria, Belgium, Bulgaria, Croatia, Czech Republic, France, Greece, Ireland, Italy, the Netherlands, Portugal, Romania, Slovakia, Slovenia and Spain that allow for ius soli acquisition combined with a variety of residence and other requirements, indeed, the Zhu doctrine may come into play.

This possibility will call for strategic decisions being made in certain families in case of Brexit. A person can enjoy certain rights attached to Union citizenship even in the case that the status as such is no longer held, even if it is merely as a flickering light of a flame that once burnt.

But how about autonomous rights to residence? Human rights treaties lay down obligations owed directly to individuals and often provide direct access for individuals to international protection mechanisms (Shaw 2014, p. 711) and remaining member states, as well as the UK, are bound by, inter alios, the European Convention of Human Rights, even though increasingly unpopular within certain political circles. In the event of state succession within the Union 'some rights linked to the possession of member state nationality and, therefore, to the citizenship of the Union, that are being exercised in the moment of gaining independence can be retained by certain categories of people' (Gonzalez Marrero 2016, p. 188). This would be the case also in Brexit Britain.

Is there a possible retention of residence rights to be established on the grounds of the European Convention of Human Rights and the doctrine developed by the European Court of Human Rights in the landmark Kuric and others $\mathcal{v}$. Slovenia? ${ }^{12}$ It could be argued that there is a strong link between the right to reside in a certain territory and the human right to private and family life as laid down in Art. 8 ECHR. ${ }^{13}$ Most probably residence rights will be frozen.

\subsubsection{The Kurić Doctrine}

The case concerns some of the so-called izbrisani of Slovenia who had been stripped of their prior status as permanent residents, and most often also turned into stateless following the missed naturalisation in the newly independent Slovenia in the early 1990s.

When Slovenia became independent, it automatically extended citizenship to any person who had been its 'internal citizen' but not to former Socialist Federal Republic of Yugoslavia citizens holding the citizenship of 
one of the other republics of the former Yugoslav federation. Permanent residents did not acquire Slovenian citizenship automatically: They had a window for opting for citizenship. Those who did not apply or missed the deadline were simply erased from the registry of permanent residents. The group of izbrisani was created: It consisted of those who lost their previously acquired rights of residence in Slovenia (Mindus 2009).

After a long saga in the Slovenian constitutional court, the matter came before the Court in Strasbourg where, on 3 March 2009, it was ruled that 'the decisions taken by States in the immigration sphere can in some cases amount to interference with the right to respect for private and family life secured by Art. $8 \$ 1$ of the Convention' and that it must be accepted that the totality of social ties between settled migrants and the community in which they are living constitute part of the concept of private life within the meaning of Art. 8' ( $\$ 351)$. The applicants were nationals of both the Yugoslav republic and one of the other republics of Yugoslavia that were not Slovenia. All had permanent residence in Slovenia as citizens of the Yugoslav Republic, which gave them - in the eyes of Strasbourg - 'a stronger residence status than long-term migrants.' The punch line of Kurić is that 'once you have lawfully established residency, you keep the rights of residence, even if the legal status of either your home State or your host State changes and, as a result of this change, your new nationality status alone would no longer give you a right to residence' (Vidmar 2013, p. 28).

Although the facts in Kuric and Brexit differ, ${ }^{14}$ the premise remains: Residency was lawfully established prior to change in legal status and, if the UK will proceed with withdrawal from the EU, that right of residence will be kept, even if the nationality status alone would no longer give a right of residence. Regardless of whether or not the person concerned resides in EU territory upon independence, by virtue of the Kuric doctrine, the residence status will be frozen. However, 'the further development of that status after independence - defrosting of the residence status - will certainly be different if the residence has been frozen in the territory of a member state or in the territory of the exited state' (Gonzalez Marrero 2016, p. 208). The Kurić formula would 'cement' the existing residence rights, but would not extend the applicability of European law to the territories exiting the EU.

The implications for second country nationals in the UK and for British citizens in the Union will be different. The freezing of rights for the first 
category will depend, once exit is effected, exclusively on domestic law's reading of the boundaries imposed by international law. Generally, there will be issues raised in relation to the enforcement in the UK of the withdrawal treaty. The protection offered by the Kuric formula to the second group has limitations. Its protection is territorially restricted. It only guarantees those rights attached to the residence status as far as the person concerned does not move to another member state. Therefore, being granted the status of long-term resident third country national is to be preferred to merely relying on the Kuric formula: Long-term resident third country nationals are not chained to one member state. ${ }^{15}$ They exercise freedom of movement akin to that of Union citizens as they acquire a right to reside in member states other than the one that granted the status.

\subsubsection{Residence Rights in the EU}

Two are the practical implications for UK nationals residing in member states with no other nationality to fall back on. First, due to the Kuric doctrine, the residence within the EU of nationals from the exited state is deemed to be legal. Even in the event of a non-negotiated cataclysmic withdrawal member states would not be allowed to consider UK nationals illegal migrants.

Second, British citizens around the Union would do well to have their position regularised as long-term resident third country nationals. Member states are not required to, but may consider facilitate the regularisation of British nationals as long-term resident third country nationals. Both the Citizens directive and the Third country nationals long-term residence directive refer to the same quantitative (five years) and qualitative (continuous residence) requirements regarding the period of residence necessary to acquire permanent residence or long-term residence status. The second country national has in practice already met the requirement to be granted a long-term residence permit as a third country national. A first policy can thus be suggested: Unless the requirements have ceased to be met, the change of status from Union citizen with right of residence to third country national with a long-term residence permit ought to be granted automatically to British citizens who have already acquired the right to permanent residence in the host member state. Basically, Brits having lived in a member state for five years or more can stay. A stronger version of this policy suggestion has been made by 
scholars who have recently suggested that 'a fairly modest legislative change to the Long-term residence directive that would mitigate the predicament of UK citizens could be the granting of Long-term resident status to mobile UK citizens, irrespective of whether they have met the continuous residence and/or other LTRD requirements' (Ziegler 2016).

Many countries require third country nationals to comply with integration requirements before becoming long-term residents, including the UK. Integration tests, that are mentioned in the Third country national long-term residence directive but not in the Citizens directive, may be a hinder for freshly minted third country nationals with British passports, probably still European in colour, who may be subjected to such tests. Another policy suggestion could be to ease, or waive, the requirement of integration tests (and/or make sure these tests are not unreasonably strict or costly) so as to facilitate the makeover from second country national to third country national.

Those having lived in the country less than five years could also be granted leave to stay: Former Union citizens living in member states since less than five years would be able to make a claim in favour of freezing rights in the process of being acquired; since the Kuric doctrine would count to protect residence rights to be taken into account for a future application for status as long-term third country national.

Residence rights will be recognised for post-Europeans in the Union. Perhaps they will be harder to enforce for second country nationals in the UK, but also their residence rights have chances of being frozen. According to Richard Gordon and Rowena Mofatt, for instance, there are two strands of case law of relevance in seeking remedy for the 'vested rights' of second country nationals: The first, relating to vested rights and the second relating to fairness and, in particular, the doctrine of substantive legitimate expectation. The question of vested rights has been explored in the context of the Immigration Rules in the case of Odelola v. Secretary of State for the Home Department. European citizens would be in a far stronger position to invoke the presumption against retrospectivity in the event that a UK withdrawal from the EU altered or removed their existing free movement rights enjoyed in the UK. But this presumption against retrospectivity is valid only 'in absence of express statutory language to the contrary' (Gordon and Mofatt 2016). According to the same source, 'it is considered likely that the common law would be astute enough to protect the pre-existing interests of EU citizens in the UK in the event of a UK withdrawal' (Gordon and Mofatt 2016). 
In sum, British citizens may thus be granted leave to stay in the Union. By the same token, we cannot exclude that second country nationals could see their residence rights frozen also in the UK.

\subsection{The Wrong Saviour?}

We have shown that there are ways to secure 'acquired residence rights' by European citizens living in the UK and British nationals living elsewhere in the Union, by relying on the Kuric doctrine. Residence rights for all other categories than family members of Union citizens and primary carers of minor Union citizens resident in the EU cannot be upheld on the basis of European law. The rights of residence linked to free movement - a most celebrated acquis and beloved by many mobile Union citizens - will not fall prey to the idiosyncrasies of the electorate in a member state, nor held hostage by static citizens as many fear. They will be saved, but not by the workings of the acquis. The most cherished entitlements of Europeans will need to be saved by international law.

As far as the content of Union citizenship is concerned, (some) rights may be frozen, but the rights that may be frozen are not rights of the kind that would make Union citizenship a supranational legal status. Indeed, we are dealing with rights, the ratio personae of which does not coincide with that of Union citizenship. Residence rights as, in general, freedom of movement are, repetita juvant, not pertaining exclusively to the citizens of the Union. Their personal scope is both over- and under-inclusive in relation to the category of Union citizens. Many have long been unconvinced by their supposed supranational character. In fact, freedom of movement is not recognised unconditionally to Union citizens (as underscored by Case C-333/13 Dano EU:C:2014:2358) and a number of third country nationals are covered by the acquis in relation to freedom of movement. Third country nationals holding a valid residence permit or visa have the right to move freely within the Schengen area for up to three months within a six-month period. The rights in relation to taking up residence for a period exceeding three months in another member state is covered by specific legal instruments, depending on their status, and subject to conditions in national legislation (e.g. blue card, intracorporate tranfers, long-term residents, researchers, students). 
Legal positions founded on the 'mutual commitment to open their respective bodies politic to other European citizens and to construct a new form ( ... of political allegiance on a European scale' - to use the phrasing of Poaires Maduro in the Rottman case - are rightly called 'supranational.' Such supranational rights associated with Union citizenship - first and foremost, the right to vote and stand in elections in the European Parliament and the right to the Citizens' initiative - will be lost with the status. Those whose nationality is no longer linked to a member state, due to the withdrawal of that State, lose their 'fundamental status' as previously conceived. They cannot invoke civis europaeus sum. The question thus arises: Is it lawful for a member state to strip their own nationals of Union citizenship? This is a question regarding the extension, not the intension of membership in the EU. So let us move on to investigate this second dimension of citizenship of the Union in the next chapter.

\section{Notes}

1. For an explanation of why the so-called precedents are not relevant, see Chapter 4.

2. Some analogies are clearly fallacious: Consider, for example, the parallel drawn between Union citizenship and the status of commonwealth citizen, a status common to all kinds of British nationality statuses and citizens of commonwealth countries. The acquisition and loss of this status is a matter to be regulated by the Commonwealth. Historically speaking, the UK allowed people from territories gaining independence to maintain the overarching subjecthood to the Commonwealth, since the latter defines its own citizens. While this analogy is fit to test the theory of internal enlargement for cases such as Scotland, Flanders and Catalonia, it has no traction in Brexit since the UK never exited the Commonwealth.

3. See, e.g. Douglas-Scott 2016. Some evidence suggests that private rights under municipal law such as property and contractual rights may be frozen according to customary international law. Doctrine is divided when it comes to automatic accession to Human Rights Treaties in case of state succession. But even if automatic accession did take place it would not help protecting the 'special rights' of EU citizens.

4. Note verbale of the Delegation of the EU to the UN 19 September $2012, \$ \mathrm{~A}_{4}$.

5. Reference re Secession of Quebec, [1998] 2 S.C.R. 217. 
6. See International Law Commission, Articles of Nationality of Natural Persons in Relation to the Succession of States (with Commentaries), 3 April 1999, Supplement No. 10 (A/54/10).

7. Ibidem, at 30 .

8. Reference is to those bound by the European Convention on Nationality, namely Austria, Bulgaria, Czeck Republic, Denmark, Finland, Germany, Hungary, the Netherlands, Portugal, Romania, Slovakia and Sweden. Besides the many reservations made to European Convention on Nationality, it might also be a dubious solution for some of these countries for internal reasons: for example, Austria enforces a ban on multiple nationalities; Sweden already has a comparatively easy naturalisation process; Denmark imposes integrations tests, etc.

9. Declaration on the Consequences of State Succession for the Nationality of Natural Persons (and Commentary), reproduced in Council of Europe, European Commission for Democracy though Law, 'Consequences of State Succession for the Nationality' CDL-INF (97).

10. Some have even pointed out that if UK citizens were non-EU citizens (third-country nationals), they could apply for asylum in the EU (and vice versa). This prospect, however, seems improbable. A more probable effect is that it will be harder also for UK to obtain extradiction from EU member states. The recent Petrubhin ruling (Case C-182/15 ECLI:EU: C:2016:630) takes a step towards EU exclusive competence over extradition treaties with non-EU countries. It may become unlawful to extradict to the $\mathrm{UK}$; there are several challenges in Ireland to the execution of British European arrest warrants following the Brexit vote.

11. Case C-20/02 Zhu and Chen (2004) ECR I-09951.

12. Application No. 26828/06, 26 June 2012 Kuric v Slovenia.

13. The connection between Art. 8 ECHR and EU law has been stressed previously: See Wiesbrock 2009 at 199 - in relation to residence rights of third country nationals who are family members of European citizens. Then again, the directive on permanent residence rights for EU citizens also regulates the residence rights of their family members (See Directive $2004 / 58 / \mathrm{EC})$.

14. There is, nonetheless, a similarity in circumstances between the cases insofar as the UK may be tempted to deny continued rights to residency to a number of citizens with non-UK member state nationality, similarly to how Slovenia denied it to those who had nationality of other states emerging from the break-up of Yugoslavia who however had, at the time of the former federation, established their permanent residency in Slovenia, just like second country nationals enjoy Treaty rights on UK soil. 
15. See Council Directive 2003/109/EC of 25 November 2003 concerning the status of third-country nationals who are long-term residents: After five years of continuous residence (Article 4 LTRD) and subject to satisfying additional criteria, LTRs acquire the right to reside in the territory of member States other than the one which granted them the long-term residence status (Article 14(1) LTRD).

\section{REFERENCES}

Carrera, S., E. Guild, and N. Chun Luk. (2016) 'What Does Brexit Mean for the EU's Area of Freedom, Security and Justice?', CEPS, July 2016, available at https://www.ceps.eu/publications/what-does-brexit-mean-eu\%E2\%80\%99sarea-freedom-security-and-justice (last accessed 30 October 2016).

Closa, C. (ed.) (2014) Troubled Membership: Dealing with Secession from a Member State and Withdrawal from the Union, RSCAS 2014/91. RSCAS Publications, Fiesole.

Douglas-Scott, S. (2016) 'What Happens to Acquired Rights in the Event of Brexit?', U.K. Const. L. Blog (16th May 2016), available at https://ukconsti tutionallaw.org/2016/05/16/sionaidh-douglas-scott-what-happens-toacquired-rights-in-the-event-of-a-brexit/ (last accessed 30 October 2016).

Gonzalez Marrero, G. (2016) Civis Europaeus Sum? Consequences with Regard to Nationality Law and EU Citizenship Status of the Independence of a Devolved Part of an EU Member State, Nijmegen: Wolf Legal Publishers.

Gordon, R., and R. Mofatt (2016) Brexit: The Immediate Legal Consequences, Report for The Constitution Society, available at http://www.consoc.org.uk/wp-con tent/uploads/2016/05/Brexit-PDF.pdf (last accessed 30 October 2016).

Kochenov, D. (2016) 'Brexit and the Argentinianisation of British Citizenship: Taking Care Not To Overstay Your 90 Days in Rome, Amsterdam or Paris', VerfBlog, 24 June 2016, available at http://verfassungsblog.de/brexit-andthe-argentinisation-of-british-citizenship-taking-care-not-to-overstay-your-90days-in-rome-amsterdam-or-paris/ (last accessed 30 October 2016).

Mindus, P. (2009) 'The Contemporary Debate on Citizenship. Some Remarks on the Erased of Slovenia', 9 Revus European Constitutionality Review 29-44. Slovenian version transl. by Jernej Ogrin.

Shaw, M. (2014) International Law, 7th ed., Cambridge: CUP.

Vidmar, J. (2013) 'The Scottish Independence Referendum in an International Context', 51 Canadian Yearbook of International Law 259-288.

Wiesbrock, A. (2009) Legal Migration to the European Union: Ten Years After Tampere, Maastricht: Wolf. 
Ziegler, R., UK Citizens as Former EUY Citizens: Predicament and Remedies, EUDO Forum Debates 'Freedom of Movement Under Attack: Is it Worth Defending as the Core of EU Citizenship?, available at http://eudo-citizen ship.eu/commentaries/citizenship-forum/citizenship-forum-cat/1586-free dom-of-movement-under-attack-is-it-worth-defending-as-the-core-of-eu-citi zenship?showall=\&start=12 (last accessed 12 November 2016).

Open Access This chapter is licensed under the terms of the Creative Commons Attribution 4.0 International License (http://creativecommons.org/licenses/ by $/ 4.0 /$ ), which permits use, sharing, adaptation, distribution and reproduction in any medium or format, as long as you give appropriate credit to the original author(s) and the source, provide a link to the Creative Commons license and indicate if changes were made.

The images or other third party material in this chapter are included in the book's Creative Commons license, unless indicated otherwise in a credit line to the material. If material is not included in the book's Creative Commons license and your intended use is not permitted by statutory regulation or exceeds the permitted use, you will need to obtain permission directly from the copyright holder.

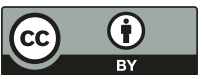

